Studia nad Autorytaryzmem i Totalitaryzmem 43, nr 3 Wrocław 2021

https://doi.org/10.19195/2300-7249.43.3.30

\author{
AGNIESZKA ZAJĄCZKOWSKA-DROŻDŻ \\ ORCID: 0000-0003-2736-1618 \\ Uniwersytet Jagielloński \\ agnieszka.zajaczkowska@uj.edu.pl
}

\title{
Działalność konspiracyjna Żydów w Krakowie jako reakcja na niemiecką politykę Zagłady
}

Slowa kluczowe: żydowska konspiracja, Kraków, opór zbrojny, getto krakowskie.

\section{UNDERGROUND RESISTANCE OF JEWS IN KRAKOW IN REACTION TO GERMAN EXTERMINATION POLICY}

\begin{abstract}
This article presents a detailed history of what the underground resistance of Krakow's Jews consisted of during the Second World War. It incorporates examples of different types of passive resistance applied as well as the history of illegal organisations that undertook aid activities and Jewish partisan actions. The activities of the partisans in the Krakow forests is scrutinised, together with how contact networks and the production of illegal documents were organised. The article contains a comprehensive analysis of the greatest military achievement of Krakow Jews, known as "attack on Bohemia", which was remembered as a momentous occasion. Finally, the article shows the evolution of the idea of resistance to the Germans and their anti-Jewish policy among Jewish youth.
\end{abstract}

Keywords: Jewish underground Krakow, armed resistance, Krakow ghetto.

W literaturze przedmiotu przyjęło się określać wszelkie formy sprzeciwu Żydów wobec poczynań niemieckiego okupanta w czasie wojny mianem ruchu oporu, niezależnie czy dotyczy to zorganizowanych akcji zbrojnych, czy pojedynczych aktów odwagi. Pozostając przy tej powszechnie przyjętej nomenklaturze, $\mathrm{w}$ artykule przedstawię historię działalności konspiracyjnej i podjętych aktywności przeciwko niemieckiej polityce eksterminacyjnej Żydów w Krakowie. 
Opór i walka zbrojna jako reakcja części Żydów na antysemicką politykę nazistowską nie były zjawiskiem powszechnym, gdyż wiązały się z ogromnym niebezpieczeństwem. W czasie wojny Żydzi podejmowali różne formy biernego sprzeciwu, zdając sobie sprawę z tego, że łamią obowiązujące prawo i może ich spotkać surowa kara. Żydzi wyrażali swój sprzeciw przez nieprzestrzeganie wydanych zakazów, jak choćby utrzymywania kontaktów ze „stroną aryjską”. Dan Michman w swojej analizie zjawiska oporu żydowskiego w czasie wojny wskazuje na bardzo szerokie spektrum postaw, które z perspektywy czasu możemy rozumieć jako opór, nie zawężając swojej perspektywy jedynie do walki zbrojnej, jego najbardziej radykalnej formy ${ }^{1}$.

Realizacja prób zbrojnego oporu przeciw Niemcom w Krakowie, podobnie jak w innych miejscach, podjęta została stosunkowo późno, dopiero w czasie akcji deportacyjnych do obozów zagłady, gdy do świadomości zamkniętych w getcie Żydów dotarło, że wysiedlenie jest jednoznaczne ze śmiercią. Jednak już wcześniej podejmowano kroki, które możemy określić mianem biernego oporu, czyli działań bez użycia broni. Jego celem było bądź to złagodzenie skutków wydawanych przez Niemców rozporządzeń, ich sabotowania, przygotowania zaplecza pod przyszłą działalność konspiracyjną, bądź realizacji przedwojennych idei związanych z wyjazdem do Palestyny.

Przedstawienie historii ruchów konspiracyjnych i ruchu oporu w getcie krakowskim wiąże się z wieloma trudnościami. Podstawowym problemem jest stosunkowo niewielka liczba pozostawionych relacji i zeznań uczestników bądź świadków tych wydarzeń. Przywódcy i główni uczestnicy zorganizowanego w getcie oporu zginęli w czasie wojny, a o działalności tych grup pozostali mieszkańcy getta niewiele wiedzieli. W dostępnych dokumentach informacji jest niewiele i często są one sprzeczne. Wiele kwestii jest niejasnych, a wzmianki o nich pojawiają się $\mathrm{w}$ pojedynczych wspomnieniach, co utrudnia ich weryfikację. W dokumentach źródłowych nawet najważniejsze fakty, dotyczące dat, miejsc i nazwisk związanych z głównymi wydarzeniami niejednokrotnie są odmienne.

Duże rozbieżności występują zwłaszcza między relacjami żydowskich uczestników tamtych wydarzeń a wspomnieniami działaczy Polskiej Partii Robotniczej, czyli dwóch ugrupowań, które współpracowały z sobą w organizowaniu akcji konspiracyjnej. Zasadnicze różnice w tych relacjach dotyczą zwierzchnictwa i zależności jednej organizacji od drugiej. W relacjach członków PPR znajdujemy jasne stwierdzenia, że to właśnie ta partia była inicjatorem i koordynatorem akcji zbrojnej w getcie krakowskim, a Żydowska Organizacja Bojowa jej podlegała ${ }^{2}$. Natomiast w relacjach członków ŻOB wyraźnie zaznaczano niezależność i inicjatywę tej grupy, podając informacje jedynie o współpracy z PPR,

1 D. Michman, Holocaust Historiography. A Jewish Perspective. Conceptualizations, Terminology, Approaches and Fundamental Issues, London-Portland, Or 2003, s. 217-248.

2 E. Sztulbach, Powstanie Żydowskiej Organizacji Bojowej ŻOB, Archiwum Żydowskiego Instytutu Historycznego AŻIH 301/4803; Feliks Harndorf, Relacja niezatytułowana, AŻIH 301/586. 
która była konieczna z powodu braku uzbrojenia i wojskowego przeszkolenia członków ŻOB ${ }^{3}$.

Oprócz materiałów źródłowych w artykule wykorzystano zarówno opublikowane wspomnienia uczestników omawianych wydarzen ${ }^{4}$, jak i opracowania dotyczące historii ludności żydowskiej w Krakowie w czasie wojny, ze szczególnym uwzględnieniem pozycji, w których został podjęty temat organizacji ruchu oporu ${ }^{5}$. Żydowscy bohaterowie tych wydarzeń to głównie młodzi ludzie, którzy przed wojną nie mieli nic wspólnego $\mathrm{z}$ konspiracją i walką zbrojną. Ich opór i chęć walki z wrogiem zrodziły się $w$ trakcie istnienia getta i były odpowiedzią na okrucieństwa, jakich doznali ze strony Niemców. Idea walki zbrojnej była romantyczną wizją, której realizacji podjęli się, nie mając żadnego przygotowania do jej prowadzenia. Przywódców organizacji bojowej Hela Schüpper-Rufeisen oceniła w taki oto sposób:

Byli wszyscy pedagogami, wychowawcami na wielką skalę [...]. Przywództwo ich miało jednak charakter na wskroś duchowy. Znali dusze swych wychowanków i umieli torować im drogę, w najtrudniejszym nawet życiu być dla nich wzorem bojowości i oddania. Ale zawsze ich przywództwo miało charakter duchowy [...]. Oficerami zatem nie byli nigdy ${ }^{6}$.

${ }^{3}$ Uwagi do wywiadu Harndorfa Feliksa, AŻIH 301/586, k. 9.

4 Zob. m.in. A. Bauminger, The Fighters of the Cracow Ghetto, Jerusalem 1986; A. Bieberstein, Zagłada Żydów w Krakowie, Kraków 1985 i 2001; I. Cukierman, Nadmiar pamięci. Siedem owych lat. Wspomnienia 1939-1946, Warszawa 2000; idem, The Jewish Fighting Organization Z.O.B. - its establishment and activities, Jerusalem 1976; G. Draenger, Pamiętnik Justyny, Kraków 1946; Ch. Folman-Raban, Nie rozstawałam się z nimi..., Warszawa 2000; C. Lubetkin, Zagłada i powstanie, Warszawa 1999; M. i M. Mariańscy, Wśród przyjaciół i wrogów. Poza gettem w okupowanym Krakowie, Kraków 1988; S. Rotem, Wspomnienia bojowca ŻOB, Warszawa 1993; H. Rufeisen-Schüpper, Pożegnanie Miłej 18, Kraków 1996.

5 Zob. m.in. A. Nirensztein, Ruch oporu Żydów w Krakowie pod okupacją hitlerowska, „Biuletyn Żydowskiego Instytutu Historycznego" 1952, nr 3; D. Agatstein-Dormontowa, Żydzi w Krakowie w okresie okupacji niemieckiej, [w:] Kraków w latach okupacji 1939-1945. Studia i materiały, („Rocznik Krakowski” 31), Kraków 1949-1957; J. Bratko, Gestapowcy, Kraków 1985; A. Löw, M. Roth, Krakowscy Żydzi pod okupacją niemiecka 1939-1945, Kraków 2014; K. Zimmerer, Zamordowany świat. Losy Żydów w Krakowie 1939-1945, Kraków 2004; eadem, Kronika zamordowanego świata. Żydzi w Krakowie w czasie okupacji niemieckiej, Kraków 2017; M. Natkaniec, Żydowska konspiracja zbrojna w Krakowie i rejonie krakowskim w okresie okupacji hitlerowskiej, „Krzysztofory” 1988; D. Swałtek-Niewińska, Powiat bocheński, [w:] Dalej jest noc. Losy Żydów w wybranych powiatach okupowanej Polski, red. B. Engelking, J. Grabowski, Warszawa 2018; M. Grądzka-Rejak, Ruch oporu w gettach i obozach, (seria „Polska walcząca”), Warszawa 2017; K. Kołodziejska, Gusta Dawidson-Draenger - kronikarka żydowskiego ruchu oporu w Krakowie, [w:] Przewodniczka po Krakowie emancypantek, red. E. Furgał, Kraków 2012; E. Długosz, Gusta Draenger, [w:] Wojna to męska rzecz? Losy kobiet w okupowanym Krakowie w dwunastu odstonach, red. A. Czocher et al., Kraków 2011; A. Zajączkowska-Drożdż, Od dyskryminacji do eksterminacji. Polityka Trzeciej Rzeszy wobec Żydów w Krakowie 1939-1943, Kraków 2020.

${ }^{6}$ H. Schüpper-Rufeisen, op. cit., s. 68. H. Schüpper-Rufeisen była członkiem i łączniczką Żydowskiej Organizacji Bojowej. 
Organizacja oporu zbrojnego w samym getcie krakowskim była bardzo niebezpieczna i wiązała się z dużym ryzykiem. $Z$ pewnością samo usytuowanie getta u podnóża Krzemionek, skąd Niemcy mieli świetny punkt obserwacyjny i mogli bez trudu monitorować wszystkie ulice getta, nie sprzyjało tworzeniu tajnych organizacji. Wspominał o tym Henryk Zwi Zimmermann:

Getto krakowskie, małe, leżące u podnóża Krzemionek, umiejscowione na przedmieściu zdominowanym przez niską zabudowę, otoczone wysokimi budynkami, na których wystarczyło Niemcom ulokować małą liczbę stanowisk kontrolnych, aby obserwować stale każdy dom i zaułek, nie nadawało się do jakiegokolwiek efektywnego oporu, nie mówiąc już o tym, że garstka bojowników mająca bronić kilkutysięczną ludność getta posiadała nikłe uzbrojenie ${ }^{7}$.

Co więcej getto było stosunkowo małe ${ }^{8}$, a kary ze strony Niemców za akcje sabotażowe skutecznie paraliżowały działania mieszkańców. Dlatego wszelkie akcje sabotażowe i bojowe podejmowane przez uczestników konspiracji organizowane były poza gettem.

\section{Opór bierny}

Omawiając działalność podziemną Żydów w Krakowie, nie można pominąć inicjatyw, które nie przybrały formy zamachów zbrojnych, były jednak prowadzone w duchu oporu wobec antyżydowskiej polityki Niemców. Tak działającą grupą była organizacja Sneh, o której najwięcej informacji znajdujemy we wspomnieniach Zimmermanna. Według niego grupa składała się z czołowych działaczy społecznych przedwojennej gminy żydowskiej w Krakowie. Od pierwszych dni okupacji podjęli się oni tworzenia struktur działalności podziemnej. Zimmermann wspominał: „Zdawaliśmy sobie sprawę, że cokolwiek się wydarzy, konieczne jest przygotowanie zalążka podziemnej organizacji, złożonego z ludzi bezwzględnie zaufanych, związanych wcześniejszą współpracą - dla organizowania i ratowania życia członków społeczności żydowskiej"9. Rozpoczęto działalność pod przywództwem syjonisty Leona Salpetera, aptekarza i członka zarządu Judenratu. Grupa składała się z dziesięciu przedstawicieli różnych odłamów syjonizmu, byli to: dr Mojżesz Spira, Leon Bulwa, Ryszard Abrahamer, Wilek Grünberg, Wilek Grüner, Gerszon Blüth, Dolek Liebeskind, Szmuel Bajuk, Henryk Apsel, Henryk Zvi Zimmermann. Nazwa „Sneh”, nawiązywała do Biblii i oznaczała niezniszczalny krzew gorejący. Większość członków grupy zajmowała stanowiska w Judenracie lub w organizacjach charytatywnych. Ryszard Abrahamer był kierowni-

${ }^{7}$ H. Zwi Zimmermann, Przeżyłem, pamiętam, świadczę, Kraków 1997, s. 145-146.

${ }^{8}$ Getto krakowskie mogło zostać zorganizowane na stosunkowo niewielkiej przestrzeni ze względu na prowadzoną przez Niemców politykę przesiedleń i co za tym idzie znaczną redukcję liczby ludności żydowskiej w Krakowie w okresie przed utworzeniem getta. Analiza niemieckiej polityki przesiedleń Żydów z Krakowa zob. A. Zajączkowska-Drożdż, op. cit., s. 39-65.

9 Ibidem, s. 92. 
kiem Opieki Społecznej, po utworzeniu getta jego funkcję przejął Zimmermann, Gerson Blüth był szefem kuchni społecznej. Ich działalność podziemna odbywała się w urzędach Opieki Społecznej i pomieszczeniach kuchennych. Głównym i pierwszym celem, jaki postawili sobie członkowie organizacji, była nielegalna pomoc dla potrzebujących. Przed utworzeniem getta członkowie organizacji pomagali najbiedniejszym oraz tym, którzy zostali przesiedleni do Krakowa z innych miast i mieli wielkie trudności z zaspokojeniem podstawowych potrzeb. Po utworzeniu getta Sneh przeniosła tam swoją działalność i rozpoczęła pomoc Żydom w organizowaniu życia w getcie. Powołany został Komitet Obywatelski, którego głównym zadaniem było zdobywanie funduszy. Dzięki zapleczu socjalnemu Sneh wspierała działania zbrojne powstałej później Żydowskiej Organizacji Bojowej, jednak przede wszystkim skupiła swą działalność na ratowaniu życia zamkniętych w getcie ${ }^{10}$. Zimmermann tak charakteryzował cele organizacji:

My zaś, to znaczy podziemna komórka Sneh, nie wahaliśmy się podejmować akcji zbrojnych, ale pozostawaliśmy pod dowództwem rozumnego człowieka, który żądał od nas przemyślenia każdego kroku i jego przypuszczalnych konsekwencji. Od momentu zorganizowania się poszukiwaliśmy też dróg ocalenia jak największej liczby umęczonych Żydów. Pragnęliśmy, aby przetrwało możliwie wielu świadków, którzy potrafią odkryć wyzwolonemu światu czyny, określone potem jako genoside (ludobójstwo). Ażeby zbrodniarze zostali ukarani i by takie zbrodnicze czyny nie mogły się powtórzyćc ${ }^{11}$.

Od początku okupacji niemieckiej działalność podziemną prowadziły również organizacje syjonistyczne Akiba i Haszomer Hacair. Przed utworzeniem getta była to kontynuacja dotychczasowych działań, czyli przygotowań do wyjazdu do Palestyny. Przed wojną organizacje syjonistyczne zrzeszające młodzież żydowską organizowały szkolenia i kolonie, podczas których przygotowywano uczestników do wyjazdu i pracy nad stworzeniem nowego państwa żydowskiego w Palestynie. Hela Schüpper-Rufeisen, członkini Akiby, napisała:

Chodziło o to, by każdy podjął decyzję, czy jest gotów do pracy w Ruchu w dziedzinie wychowawczej, czy też przez pewien czas gotów do pracy na folwarku. Wszystko po to, aby przygotować się do uprawy ziemi Izraela i budowy naszego przyszłego państwa. [...] Czas spędzaliśmy słuchając referatów, studiując Biblię - Tanach, ucząc się języka hebrajskiego, nowych piosenek i śpiewając dużo, jak każda młodzież na wczasach ${ }^{12}$.

Opiekunką grupy składającej się z dwudziestu osób była Gusta Dawidson-Draenger. Gusta wraz z Szymonem Drängerem, przedwojennym redaktorem gazety młodzieżowej, w której zamieszczał artykuły antyhitlerowskie ${ }^{13}$, w październiku 1939 roku zostali aresztowani i osadzeni w obozie koncentracyjnym Tropau-

10 Ibidem, s. 92-94.

11 Ibidem, s. 121.

12 H. Schüpper-Rufeisen, op. cit., s. 15-16.

13 Autorką tekstów była Irena Harald, Austriaczka, zaprzyjaźniona z członkami ruchu Akiba; ibidem, s. 21. 
-Opawa. Był to sygnał ostrzegawczy dla młodzieży syjonistycznej. Zlikwidowano wtedy miejsce spotkań i ukryto książki, gazety i inne dokumenty wskazujące na przynależność do organizacji. Ich kontakty przekształciły się w potajemne, zakonspirowane spotkania. Po trzech i pół miesiącach udało się doprowadzić do zwolnienia Szymona i Gusty z obozu. Hela Schüpper-Rufeisen wspominała, że było to możliwe dzięki łapówkom, jednak nie podaje informacji, jak dokładnie przebiegał ten proceder ${ }^{14}$. Wokół Szymona i Gusty ponownie zaczęła gromadzić się młodzież syjonistyczna. Spotykano się wówczas w mieszkaniu rodziny Pauli Kurtz, przy ul. Dietla 44. Członkowie organizacji z Krakowa wyjeżdżali do Warszawy, aby wspólnie ustalać plan działania. Szymon zachęcał uczestników Akiby do wyjazdu do Warszawy i kontynuowania szkolenia - Hachszary, które było zorganizowane w celu przygotowywania młodzieży do wyjazdu i budowania nowego państwa. Jednocześnie ukończenie kursu było warunkiem otrzymania pozwolenia brytyjskiego na wjazd do Palestyny. Hela Schüpper-Rufeisen napisała: „Zdaniem Symka warunki rozwoju pracy organizacyjnej w Warszawie były dużo lepsze niż w Krakowie. Widział tam szerokie możliwości podtrzymania Ruchu i pracy syjonistycznej, [...] bo przecież wojna kiedyś się skończy i znów będą możliwości wyjazdu do Erec Izrael"15. W Warszawie utworzono Punkt Uchodźców Młodzieży Żydowskiej z Krakowa przy ul. Nalewki 10, w którym odbywały się szkolenia. Podobne kursy prowadzone były też na farmie w Kopalinach ${ }^{16}$. Głównymi wykładowcami byli Juliusz Feldhorn, Józef Wulf, Szymon Dränger, Gusta Dawidson-Draenger, a także Dolek Liebeskind. Jednak farma ta działała tylko kilka miesięcy, jej twórcy, ze względów bezpieczeństwa, postanowili przenieść się do krakowskiego getta ${ }^{17}$. Z tego fragmentu jasno wynika, że młodzież była skupiona na własnym rozwoju i możliwości wyjazdu do Palestyny po wojnie, a nie na organizowaniu oporu przeciwko Niemcom.

Inicjatywy tworzenia organizacji podziemnych przez Żydów w Krakowie były podejmowane przez środowisko żydowskie głównie we współpracy z Polską Partią Robotniczą, w której Żydzi mieli własnych przedstawicieli. Tadeusz Wroński podaje informację, że już we wrześniu 1939 roku utworzono konspiracyjną grupę młodzieży polskiej, która nie miała żadnej nazwy, skupiała członków Komunistycznego Związku Młodzieży Polskiej, Czerwonych Harcerzy, Organizacji Młodzieży Towarzystwa Uniwersytetów Robotniczych oraz Żydów z Haszomer Hacair. Na czele organizacji stali Jan Szumiec, Józef Krupa, Antoni Duński i Benek Halbreich. Grupa ta przekształciła się w grupę bojową w 1941 roku, część jej członków wstąpiła do Związku Walki Zbrojnej, a następnie do Polskiej Partii Robotniczej ${ }^{18}$.

\footnotetext{
14 Ibidem, s. 22.

15 Ibidem, s. 24.

16 Wieś między Nowym Wiśniczem a Bochnią.

17 A. Bieberstein, op. cit., s. 232.

18 T. Wroński, Kronika okupowanego Krakowa, Kraków 1974, s. 27.
} 


\section{Powstanie organizacji Iskra}

E. Sztulbach w swojej relacji wspomina o istnieniu w maju 1942 roku dwóch żydowskich organizacji bojowych w Krakowie: Żydowskiej Grupie Bojowej PPR i Żydowskiej Organizacji Bojowej, które połączyły się we wrześniu 1942 roku. Według autora relacji po połączeniu obu grup powstała Żydowska Organizacja Bojowa „,pod egidą Gwardii Ludowej”19. Podobne informacje znajdziemy w relacji Feliksa Harndorfa ${ }^{20}$. Natomiast w uwagach do relacji Harndorfa znajduje się notatka Józefa Wulfa, członka ŻOB, który twierdził, że ŻOB od początku była organizacją całkowicie niezależną od PPR, jedynie z partią tą współpracowała, łączniczką między organizacjami była Gola Mire ${ }^{21}$. Najprawdopodobniej opisywana przez Sztulbacha Żydowska Grupa Bojowa PPR to organizacja Iskra, o której dowiadujemy się również z innych publikacji 22 .

Iskra powstała w maju 1942 roku, wówczas odbyło się pierwsze konspiracyjne spotkanie Haszomer Hacair w mieszkaniu przy ul. Parkowej 1. Inicjatorem był Hersz Bauminger (pseud. Bazyli), który rozpoczął współpracę przy tworzeniu organizacji bojowej z Benkiem Halbreichem (pseud. Jakub) oraz z Golą Mire (pseud. Lidka), aktywną działaczką PPR. Podczas spotkania ustalono cele organizacji: szkolenie ludzi, przygotowywanie planów i zdobywanie broni. Do organizacji należeli między innymi: Szlomo Schein, Henek Wurzel, Roman Bromberger, Salek Biederman, Adam Lipschütz, Mieczysław Birner, Frycek Glauberman, Moniek Lewkowicz, Gena Goldfluss, Wusia Jolles, Rafałowicz i Kirschbaum. Benek Halbreich był odpowiedzialny za szkolenia i działania, Shlomo Schein za finanse, kwatery i przygotowanie dokumentów. W ciągu 1942 roku większość czasu zajmowało im dbałość o bezpieczeństwo swoich członków. Przy współpracy z PPR zorganizowano akcję rozkręcenia szyn kolejowych na trasie Kraków-Bochnia, czego efektem było wykolejenie się pociągu, oraz akcję podpalenia przystani wioślarskiej (4 czerwca 1942 roku), w której stacjonowała niemiecka policja ${ }^{23}$.

\section{Deportacje do obozów zagłady i zmiana założeń organizacji konspiracyjnych}

Pierwsze deportacje uświadomiły członkom organizacji konspiracyjnych powagę sytuacji i zmobilizowały większą liczbę młodzieży do przyłączenia się do bojowców. Wówczas też rozpoczęto planowanie zbrojnego oporu, konsultując

19 E. Sztulbach, Powstanie Żydowskiej Organizacji Bojowej ŻOB, AŻIH 301/4803.

20 Feliks Harndorf, Relacja niezatytułowana, AŻIH 301/586.

21 Uwagi do wywiadu Harndorfa Feliksa, AŻIH 301/586, k. 9. W źródłach występuje różna pisownia nazwiska: Mire lub Mirer.

22 T. Wroński, op. cit., s. 208.

23 E. Sztulbach, Powstanie Żydowskiej Organizacji Bojowej ŻOB, AŻIH 301/4803; T. Wroński, op. cit., s. 208. 
plany walki w getcie krakowskim z organizacją konspiracyjną w getcie warszawskim, która była lepiej zorganizowana. We wspomnieniach uczestników tamtych wydarzeń uderza fakt, że w chwili gdy zrozumieli, że chcą lub muszą podjąć walkę zbrojną, uświadomili sobie też swój całkowity brak kompetencji w tym zakresie. Hela Schüpper-Rufeisen tak to wspominała:

Dowiedzieliśmy się że ludzie są mordowani, wiedzieliśmy o tym wcześniej, ale to były pojedyncze przypadki, dziesiątki. Ale rozrosły się one do tysięcy. Zrozumieliśmy, że nasz koniec się zbliża, a my nic nie robimy w związku z tym. Stawało się oczywiste, że my, młodzi ludzie, musimy coś zrobić. Nie wiedzieliśmy, co robić. Wiedzieliśmy, że nie mamy broni. Z czym mogliśmy walczyć? ${ }^{24}$

\section{Również w relacji Cesi Frymer i Poli Warszawskiej czytamy:}

Po wysiedleniu czerwcowym ${ }^{25}$ nagle otworzyły się oczy młodzieży żydowskiej, zrozumiała — wysiedlenie na śmierć. [...] Tak — wysiedlenie to śmierć w krematoriach — to ostateczny koniec. Nareszcie przejrzały oczy — zrozumieliśmy. I nastąpiła reakcja. Już dość długo patrzyliśmy, jak na naszych oczach mordują najbliższych, oddzielają dzieci od matek, matki od dzieci, jak wywożą ich wszystkich na niechybną śmierć. Chęć walki z hitleryzmem, odwetu za krzywdy doznane, krzyk sprzeciwu i to pytanie — dlaczego? oto co pchnęło młodzież żydowską w szeregi partyzanckiej grupy bojowej ${ }^{26}$.

\section{Natomiast Gusta Dawidson-Draenger napisała:}

Czytaliśmy wtedy biuletyn, przesłany do nas z Warszawy, zawierający informacje o aucie gazowym w Chełmnie i o innych morderstwach Niemców, dokonywanych na Żydach na terenach zajętych przez nich na wschodzie. Postanowiono zachować czujność i konsolidować grupy młodzieży, której należało objaśnić ogólne położenie Żydów ${ }^{27}$.

\section{Tworzenie Żydowskiej Organizacji Bojowej ${ }^{28}$}

Planowanie i powstanie Żydowskiej Organizacji Bojowej w Krakowie było związane ze ścisłą współpracą z działaczami konspiracyjnymi w getcie warszawskim. Abraham Leibowicz (Laban) 21 lipca 1942 roku pojechał do Warszawy,

${ }^{24}$ H. Schüpper-Rufeisen w The Cracow Ghetto, film, Noemi Schory, 2005.

25 Deportacje Żydów z getta krakowskiego do obozów zagłady miały miejsce w czerwcu 1942 roku (wysiedlenie czerwcowe), w październiku 1942 roku (wysiedlenie październikowe) oraz w marcu 1943 roku (akcja likwidacyjna getta). Dokładny przebieg deportacji zob. A. Zajączkowska-Drożdż, op. cit., s. 163-188.

${ }^{26}$ Relacja Cesi Frymer i Poli Warszawskiej, [w:] Życie i zagłada Żydów Polskich 1939-1945. Relacje świadków, oprac. M. Grynberg, M. Kotowska, Warszawa 2003, s. 4-5.

27 G. Draenger, op. cit., s. 10.

28 Dagmara Swałtek-Niewińska wskazuje, że użycie nazwy Żydowska Organizacja Bojowa w stosunku do grupy żydowskich bojowców w Krakowie jest nadużyciem, ze względu na to, że nie nastąpiło scalenie tych grup, lecz jedynie z sobą współpracowały. O ile zgadzam się ze stwierdzeniem, że grupy te nie połączyły się w jedną organizację, o tyle nie podzielam zdania autorki o nadużyciu, gdyż w wielu relacjach uczestników tamtych wydarzeń pojawia się nazwa ŻOB w odniesieniu do tworzonej przez nich grupy krakowskiej (zob. I. Cukierman, Nadmiar pamięci; D. Libionka, 
aby omówić plany przygotowania do walki w getcie krakowskim. Współpraca Labana z Icchakiem Cukiermanem, późniejszym zastępcą komendanta Żydowskiej Organizacji Bojowej w Warszawie, rozpoczęła się w 1940 roku. Cukierman wspominał, że pierwszy raz spotkali się we Lwowie, gdzie w pierwszych latach wojny autor pracował nad stworzeniem podstaw ruchu konspiracyjnego na ziemiach będących pod okupacją radziecką ${ }^{29}$. Napisał:

Tak spotkałem człowieka, który odegrał potem bardzo ważną rolę w strefie niemieckiej. Był $\mathrm{z}$ nami przez pewien czas $\mathrm{w}$ podziemiu w strefie radzieckiej i troszczył się tam o nas. Był to Abraham Lejbowicz (Laban), mój rówieśnik. Jeszcze w strefie radzieckiej dzięki niemu byliśmy syci, mieliśmy chleb i wędlinę, a nawet buty. I to nie tylko dlatego, że pochodził z tamtych właśnie stron, ale dlatego, że był wyjątkowo zaradny, dawał sobie radę w każdej sytuacji. My pod tym względem mieliśmy dwie lewe ręce. Laban był bardzo ciepły i opiekuńczy wobec towarzyszy. Najpierw był z nami we Lwowie, a potem był jednym z filarów naszego ruchu w Krakowie. [...]. Z takim adresem, jak Labana, można było zacząć działalność w Krakowie, szukać i organizować ludzi ${ }^{30}$.

Termin przybycia Labana do getta warszawskiego zbiegł się z rozpoczęciem tam akcji deportacyjnej. Przy próbie wejścia do getta Laban został aresztowany. Jednak dzięki szybkiej reakcji przyjaciół z getta został zwolniony i powrócił do Krakowa. Tak wspominał tę sytuację Cukierman:

Teraz trzeba było jak najszybciej go ratować. Udaliśmy się jak najszybciej do różnych macherów. Po energicznych zabiegach udało nam się w końcu uwolnić Labana, przy pomocy oficera polskiej policji, za duże pieniądze. Uratowaliśmy go w ostatniej chwili. [...] Do Warszawy przyjechał, żeby naradzić się w sprawie założenia żydowskiej organizacji bojowej w Krakowie. Przyjechał do nas, by zapytać o nasze zdanie, bo wiedział, że u nas działa Blok Antyfaszystowski. Nie wiedział o rozpadzie Bloku i gotów był ryzykować życie, by usłyszeć nasze zdanie ${ }^{31}$.

Również Cywia Lubetkin opisała posiedzenie warszawskiego kierownictwa Hechaluc, po rozpoczęciu akcji deportacji Żydów do obozu zagłady 22 lipca 1942 roku i udział w nim Labana, który jak napisała: ,przybył do Warszawy na kilka dni przed pierwszą akcją. Przywiózł ze sobą plany walki w getcie krakowskim, przygotowane przez niego i jego towarzyszy. Przyjechał, by się z nami naradzić, jak zorganizować opór w jego mieście"32. Oceniła też, że w Krakowie warunki do organizowania konspiracji i działalności były trudniejsze niż w Warszawie, jako że getto było mniejsze, było w nim mniej Żydów, a także dlatego, że bojowcy byli powszechnie znani ${ }^{33}$.

Pierwszy zarys historii Żydowskiej Organizacji Bojowej, „Zagłada Żydów. Studia i Materiały” 2013, nr 9, s. 313-334 n.). D. Swałtek-Niewińska, op. cit., s. 600.

29 I. Cukierman, Nadmiar pamięci, s. 36.

30 Ibidem.

31 Ibidem, s. 141.

32 C. Lubetkin, op. cit., s. 63-64.

33 Ibidem, s. 83. 
Warszawską Żydowską Organizację Bojową (ŻOB) powołano 28 lipca 1942 roku $^{34}$. Natomiast w Krakowie, w sierpniu 1942 roku, utworzona została organizacja bojowa He-Chaluc ha-Lochem (Organizacja Bojowa Żydowskiej Młodzieży Chalucowej - Walczący Pionier), skupiająca około stu członków. Powstała ona dzięki współpracy syjonistycznych organizacji Dror z Abrahamem Lejbowiczem na czele oraz Akiby, której przewodniczył Dolek Liebeskind. Ideologicznie ugrupowania te bardzo się różniły od siebie, jednak postanowiły podjąć wspólną walkę z okupantem. Na czele nowej organizacji stanęli: Lejbowicz, Dolek Liebeskind, Szymon Dränger oraz Moniek Eisenstein. He-Chaluc ha-Lochem, utrzymując niezależny status, pozostawała w bliskim kontakcie $\mathrm{z}$ warszawską Żydowską Organizacją Bojową. Organizowali nielegalne podróże koleją w celu wymiany informacji i planów. Laban często wyjeżdżał do Warszawy, konsultując działania w Krakowie z przedstawicielami ŻOB w Warszawie, Icchak Cukierman odwiedzał Kraków. Cukierman na temat tych podróży napisał:

Wydaje mi się, że poza mną nikt nie podróżował tak dużo jak łączniczki. W pierwszym okresie, gdy jeszcze można było podróżować, towarzysze wyjeżdżali od czasu do czasu w teren. Ale od założenia getta, a nawet jeszcze wcześniej, byłem jedynym mężczyzną, który podróżował. Do nas przyjeżdżał od czasu do czasu Laban, a także Mordechaj Tenenbaum, ale on raczej rzadko podróżował. Ja jeździłem do Krakowa raz w miesiącu. W długie podróże, do dziesiątków miejscowości, spośród mężczyzn jeździłem tylko ja ${ }^{35}$.

Przez cały okres istnienia getta krakowskiego Hela Schüpper-Rufeisen była łączniczką między tymi dwoma miastami.

Wszyscy wstępujący w szeregi ŻOB składali uroczystą przysięgę ${ }^{36}$. Z założenia mieli być zorganizowani w pięcioosobowe grupy, a każda grupa miała być samowystarczalna, mieć własnego przewodnika i łącznika, własną broń, zapasy żywności, ekwipunek oraz plan działania. Członkowie poszczególnych grup mieli znać tylko osoby ze swojej grupy. Jednak nie udało się utrzymywać pełnej konspiracji — ze względu na przyjaźń i międzyludzkie relacje wśród uczestników ruchu, którzy stracili już wielu bliskich i mieli za sobą liczne tragiczne przeżycia. Dążyli oni do spędzania czasu w przyjacielskim otoczeniu (często przyjaciele $\mathrm{z}$ organizacji byli jedynymi bliskimi ludźmi, jacy im pozostali) ${ }^{37}$.

Rejza Klingberg, wspominając przystąpienie do krakowskiej ŻOB, cytuje słowa Labana:

Przestrzegał, że nie wolno nam zrażać się małymi wynikami. Mówił, że wysiłki nasze są niewspółmierne z ewentualnymi wynikami, bo jesteśmy śmiesznie małą garstką wobec przemożnego wroga. Ludzie nasi nie przywykli do pracy konspiracyjnej, a tu konspiracja musiała być podwójną, przy pracy samej i w całym naszym życiu nielegalnym na fałszywych papierach.

34 Ibidem, s. 69.

35 I. Cukierman, Nadmiar pamięci, s. 80.

36 Ghetto Fighters House Archive 113/05250R'M, za: He-Chaluc ha-Lochem.

37 G. Draenger, op. cit., s. 39-40. 
Wiele też z naszych dziewcząt zginęło nie za pracę konspiracyjną, ale z powodu swego pochodzenia żydowskiego. Laban tłumaczył mi, że celem naszym jest czynić maximum tego, co jest w granicach naszych możliwości, że należy ratować honor żydowski i zachować postawę moralną wobec wydarzeń, które nie mają precedensu w historii ${ }^{38}$.

Natan Gross we wspomnieniu o Dolku Liebeskindzie ${ }^{39}$ przedstawił swoje refleksje na temat motywacji tej grupy młodych Żydów, którzy byli zebrani wokół Dolka, do organizowania oporu i walki przeciw Niemcom. Gross przyjaźnił się zarówno z Dolkiem, jak i z jego siostrą Miriam. Jednak sam nie był zaangażowany w organizację oporu, był przyjacielem i obserwatorem. Jego zdaniem w grupie panowało przeświadczenie, że nie przeżyją wojny. Ta pewność była motywacją do walki. Nie chcieli walczyć o życie, chcieli zginąć w walce. Wiedzieli, że nie przeżyją, uważali, że ci, którzy wierzą w przetrwanie wojny, są w wielkim błędzie. Dlatego, według niego, postanowili umierać $\mathrm{z}$ honorem, w walce i byli pewni, że to najlepsza rzecz, jaka ich może jeszcze spotkać. Celem stała się śmierć z godnością. Również Hela Schüpper-Rufeisen wspominała:

O! Jak bardzo pragną zemsty, dużej czy małej, byle nie stać z opuszczonymi rękami! O! Jak bardzo są do tego nieprzygotowani. Bez przeszkolenia wojskowego, bez żadnego pojęcia o konspiracji. Ale mają bardzo silną wolę walki przeciw niemieckim zbrodniarzom. Jeśli paść — to z bronią w dłoni, z głową wzniesioną do góry! Pomścić się! Za ojca, za matkę, za cały naród żydowski ${ }^{40}$.

Natomiast Justyna Draenger napisała: „Każdy z nas aż do tej chwili pogrążony był w swoim własnym świecie zainteresowań, ale z walką praktyczną nie miał dotychczas nic wspólnego. Nie dowierzaliśmy więc swym własnym siłom, a żaden z nas nie miał ani szkoły, ani rutyny wojskowej"41.

\section{Organizacja pracy i pierwsze działania ŻOB}

Miejscem spotkań bojowców było mieszkanie rodziców Szymka Lustgartena przy ul. Józefińskiej 13, jego rodzice zostali wywiezieni podczas czerwcowego wysiedlenia ${ }^{42}$. Hela Schüpper-Rufeisen wspominała:

Do niewielkiego, dwupokojowego mieszkania wciąż przychodziła młodzież z getta, z Krakowa i z miasteczek bliskich i dalekich. Ruch był nieustanny [...]. Krzeseł było niewiele, siedzieliśmy więc na łóżkach i na podłodze. Niektórzy stali, rozmawiali, śmiali się, a nieraz i płakali. Każdy z nich już przeżył niejedno piekło. Większość już nie ma rodziny ani własnego dachu

38 Rejza Klingberg, Napad na Cyganerię, AŻIH 301/1740.

39 Natan Gross, Wspomnienie o Dolku Liebeskindzie i paru członkach jego grupy, AŻIH $301 / 424$.

${ }^{40}$ H. Schüpper-Rufeisen, op. cit., s. 46.

41 G. Draenger, op. cit., s. 11.

42 H. Schüpper-Rufeisen, op. cit., s. 45-46. 
nad głową. Każdy z nich czeka rozkazu, są gotowi na wszystko. Może pójdą do lasu? Albo będą łącznikami? [...] Oni wierzą swoim wychowawcom i kierownikom... Wierzą w Dolka, Symka i Labana ${ }^{43}$.

Szymon Dränger zorganizował „,biuro techniczne”, w którym pracowano nad wyrabianiem fałszywych dokumentów dla członków organizacji, aby umożliwić im swobodne poruszanie się między gettem a „stroną aryjską”. Bardzo dużym zaangażowaniem w tę pracę konspiracyjną wykazał się Juda Tannenbaum, który miał wiele znajomości we wszystkich urzędach i dzięki temu udawało mu się zdobywać blankiety do dokumentów. Natomiast Szymon świetnie potrafił podrabiać podpisy, czym zyskał sobie sławę. Chawka Folman-Raban ${ }^{44}$ wspominała, jak jeździła z Warszawy do Krakowa po dokumenty, a Józef Bartko w swojej książce przytacza słowa SS Obersturmführera Kurta Heinemeyera, który był funkcjonariuszem krakowskiego gestapo: „Dränger umiał po kilkuminutowym ćwiczeniu tak podrobić podpis, że właściciel nie poznawał, iż podpis jest sfałszowany"45. Początkowo Szymon nosił wszystkie pieczątki przy sobie, jednak z biegiem czasu liczba dokumentów i rzeczy niezbędnych do ich tworzenia była zbyt duża i musiał zorganizować biuro. Powstało ono przy ul. Nadwiślańskiej $1^{46}$.

Rejza Klingberg w swojej relacji wspominała, że w początkowym okresie mieli bardzo mało pracy i zleceń: „Gdy Laban dawał komuś choćby najmniejsze zlecenie, zazdrościło mu się, uważając, że jest wybranym" 47 . W pierwszych miesiącach działalności bojowcy skupili się na wysyłaniu ludzi do różnych miast, aby stworzyć sieć kontaktów, a także na drukowaniu ulotek oraz wyrabianiu fałszywych dokumentów ${ }^{48}$.

Pierwsze akcje mające na celu zaopatrzenie członków organizacji były akcjami rabunkowymi. Aby zdobyć odzież i pieniądze niezbędne do prowadzenia dalszych działań, podejmowano wszelkie możliwe starania. W relacji Cesi Frymer i Poli Warszawskiej czytamy:

Zaczęły się wypady — pierwsze z nich to rabunkowe — trzeba było przecież dużo pieniędzy na utrzymanie ludzi i ich ekwipunek. Sposobności było wiele. W tym czasie (po wysiedleniu) dużo mieszkań wraz z całym ich bogactwem stało opróżnionych, dużo ludzi bogaciło się nagle, dużo posiadało olbrzymie majątki sprzed wojny. Cel uświęca środki — trzeba było być wyekwipowanym, trzeba było dużo pieniędzy na utrzymanie i kenkarty — zaczęły się rabunki, terroryzowanie ludzi. Tak, to była trudna robota. Dużośmy o tym dyskutowali, nie wszystkim etyka i wychowanie pozwoliły na bezkompromisowe podejście do tych spraw, doszliśmy jednak do tego, że niestety tak trzeba. Nie wolno jednak było zapuścić się zbyt głęboko i świadomie przejść nad tym do porządku dziennego ${ }^{49}$.

43 Ibidem, s. 46.

44 Ch. Folman-Raban, op. cit., s. 79.

45 J. Bratko, op. cit., s. 63.

46 G. Draenger, op. cit., s. 36-38.

47 Rejza Klingberg, Napad na Cyganerię, AŻIH 301/1740.

48 Ibidem.

49 Relacja Cesi Frymer i Poli Warszawskiej, s. 5. 
W sierpniu 1942 roku opublikowano pierwszy numer podziemnej gazetki bojowców krakowskich „He-Chaluc ha-Lochem”. Pismo to tworzyli Szymon i Gusta Drängerowie. Raz w tygodniu rozprowadzane było w liczbie 250 egzemplarzy. Artykuły publikowane w gazetce dotyczyły sytuacji Żydów w okupowanej Polsce, syjonizmu, a także przyszłości Żydów. Oprócz „He-Chaluc ha-Lochem” w getcie krakowskim ukazywała się od 1 września 1942 roku do grudnia 1942 roku gazetka „Głos Demokraty” podziemne pismo, wydawane w mniej więcej sześćdziesięciu egzemplarzach ${ }^{50}$.

\section{Akcje w podkrakowskich lasach}

Wśród bojowców panowało przekonanie, że w lasach koło Krakowa rozwija się polska partyzantka, dlatego za główne zadanie postanowiono sobie wysyłanie pięcioosobowych grup do lasu i tworzenie partyzantki żydowskiej. Justyna Draenger napisała:

Praca, to znaczyło wtedy — pójść w las. Te lasy były jeszcze wciąż legendą. Nikt stamtąd nie wrócił, nikt ich nie znał. Jak zorganizowane tam jest życie? Ale każdy wiedział, że tam się coś dzieje, że tam się tworzy wielka walka i wszyscy się do niej rwali, choć zbliżała się jesień, tak bardzo nieprzychylna dla pracy w terenie [...] każdy kto się decydował, przez sam fakt decyzji stawał się lepszy, czystszy i coś na kształt niewidzialnej aureoli bohaterstwa otaczało jego osobę $e^{51}$.

Hela Schüpper wyjechała do Warszawy, aby zebrać chętnych z tamtejszego getta do przyjazdu do Krakowa i przyłączenia do tworzonej partyzantki. Zebrała fotografie do dokumentów od dziesięciu osób i wraz z Edwinem Weissem i Salo Kanałem wróciła do Krakowa. Po przybyciu do getta Dolek zwrócił się do niej:

Słuchaj Helu, mamy dla ciebie bardzo poważną robotę, najpoważniejszą i mamy wielką nadzieję, że tobie się to uda. A więc słuchaj, ludzi mamy odważnych i gotowych do pójścia do lasu. Ale nie mamy broni. Broń możemy kupić w Warszawie za pośrednictwem Polskiej Partii Robotniczej. Jeśli się zgadzasz, to pojedziesz i przywieziesz nam broń ${ }^{52}$.

Dwa dni później Hela otrzymała złoto na zakup broni i wyjechała do Warszawy. Wszystko odbyło się zgodnie z planem, zakupiła broń - pięć rewolwerów, amunicję i dwa kilogramy dynamitu. Wspominała: „Rewolwery zawiązuję koło pasa, a proch wkładam do mojej torby podróżnej i przykrywam brudną bielizną. Pomimo mojego lęku o skarb, który wiozę i mimo bólu brzucha, podróż jakimś cudem przechodzi spokojnie, bez żadnych rewizji" ${ }^{53}$. Przywieziona do Krakowa broń wywołała wielką euforię wśród członków ŻOB. Kolejnym krokiem

50 Stanisław Ślusarczyk, Relacja niezatytułowana, AŻIH 301/4591.

51 G. Draenger, op. cit., s. 39.

52 H. Schüpper-Rufeisen, op. cit., s. 51.

53 Ibidem, s. 53. 
przygotowującym do akcji wyjścia do lasu było zorganizowanie w różnych miastach punktów wsparcia dla partyzantów. Wysłano łączników, aby wynajmowali mieszkania, które będą punktami rezerwowymi dla bojowców. Hela napisała:

Nasi byli pełni zapału. Coś niby święte wzruszenie nie pozwalało im myśleć o niczym innym, jak o działaniu. Jutro się miało rozpocząć dla nich to cudowne życie. Byli pierwsi. Czuli, że torują drogę całemu ruchowi, że muszą zrobić wszystko, by stać się godnymi pionierami. $\mathrm{W}$ napięciu czekali ${ }^{54}$.

Opis przebiegu akcji, jaką zorganizowali bojowcy, znajduje się przede wszystkim w Pamiętniku Justyny autorstwa Gusty Dawidson-Draenger oraz we wspomnieniach Heli Schüpper-Rufeisen. Według tych relacji pierwszą piątkę, która wyruszyła do lasu niedaleko Miechowa, tworzyli: Baruch Weksner (Benek), Edwin Weiss, Salo Kanał (Adaś), Zygmunt Mahler (Zyga) i Juda Szmerlowicz (Ignaś). Grupa wyposażona była w dwa rewolwery. Bojowcy byli przekonani, że w lasach działa dobrze zorganizowana partyzantka, do której oni dołączą. Dzięki porozumieniu z PPR na stacji kolejowej czekał na nich przewodnik, który zaprowadził ich na nocleg do chaty przy lesie. Rano inny przewodnik wprowadził ich do lasu, gdzie błądzili przez jakiś czas. Następnie przewodnik ich w nim zostawił. Niestety w żadnej z tych relacji nie podano nic na temat przewodników oprócz tego, że byli to członkowie PPR.

Ponieważ bojowcom w lesie przez cały dzień nie udało się znaleźć grup partyzanckich, powrócili do tej samej chaty na nocleg. Tym razem nie zostali mile przyjęci i musieli wtargnąć siłą. W nocy usłyszeli żandarmów zbliżających się do chaty i uciekli do lasu. Okazało się, że PPR na tym terenie nie działała i nie istniała żadna partyzantka, do której mogliby dołączyć. Żandarmeria ostrzeliwała las, więc bojowcy spędzili trzy doby, ukrywając się. Byli głodni i wykończeni. Zorganizowali próbę zdobycia broni z posterunku policji, jednak nie udało im się dostać do środka budynku. W tej sytuacji wysłali Edwina Weissa do Krakowa, do kierownictwa, aby zdał relację i otrzymał dalsze rozkazy. Kierownictwo rozkazało opuścić las, powrócili więc do getta ${ }^{55}$. Ta nieudana próba stworzenia żydowskiej partyzantki wskazuje, że bojowcy nie byli dobrze poinformowani o sytuacji panującej w lasach. Ich oczekiwania i wiedza były zupełnie nieadekwatne do realiów. Można stąd wysnuć wniosek, że współpraca z PPR w zakresie łączności była niewystarczająca. Zresztą wówczas oddziały Gwardii Ludowej dopiero się formowały, o czym Żydzi udający się do lasu nie wiedzieli. Warto też wskazać na negatywne nastawienie do nich Polaków.

W kolejnej wyprawie do lasu wzięli udział Baruch Weksner, Juda Szmerlowicz, Salo Kanał, Zygmunt Mahler. Tym razem byli lepiej przygotowani i wyposażeni niż poprzednio. Jak wspominała Hela:

\footnotetext{
54 Ibidem, s. 65.

55 Ibidem, s. 65-67.
} 
Znaleźli odpowiedni teren. Tu rozbili namioty. Rozpoczęła się praca. Całymi dniami robili pomiary, rysowali mapy: zorientowali się w okolicy, zbadali obiekty działania, ustalili bazy operacyjne. Nakreślili punkty wypadowe, spenetrowali całą okolicę w promieniu kilkunastu kilometrów. Rozbudowali schrony, przygotowywali grunt pod pracę. Byli wyłącznie w lesie. To był ich cały świat. Nie oddalali się stąd ani na krok, do wsi nie chodzili. Znali tylko jednego czy dwóch gospodarzy na skraju lasu. Co kilka dni zaglądali w pojedynkę do wsi, zaopatrywali się w żywność i ukradkiem wracali do boru ${ }^{56}$.

Podczas jednej z wypraw po pożywienie Weksner i Szmerlowicz zostali przyłapani w chatce przez żandarma, policjanta i leśniczego. Podczas tego incydentu Weksner zdołał zastrzelić żandarma i ranić policjanta. Jednak bojowcy mieli tylko jeden pistolet, w związku z tym nie mogli się obronić. Zostali zastrzeleni. Pozostała dwójka dowiedziała się o tym od chłopa, w którego chacie doszło do strzelaniny. Chłop poszedł do lasu i ostrzegł bojowców, żeby nie wybierali się więcej do wioski, i opowiedział o zdarzeniu. Salo Kanał i Zygmunt Mahler wrócili do getta, aby przekazać informację kierownictwu. Po tych incydentach bojowcy zrezygnowali z organizowania bojówek w lasach. Tym bardziej że zbliżała się zima, a tworzenie partyzantki w jeszcze cięższych warunkach przerastało ich możliwości ${ }^{57}$.

\section{Zmiana priorytetów - akcje na terenie Krakowa}

Ze względu na porażkę, jaką ponieśli bojowcy w lasach, oraz pod wpływem szoku wywołanego drugim wysiedleniem 28 października 1942 roku i zmniejszeniem getta, przywódcy organizacji zdecydowali się skupić uwagę na akcjach sabotażowych w Krakowie. Ich zapał do walki wzrastał, o czym świadczą słowa Gusty Dawidson-Draenger: „Trzeba było wstrząsnąć ich zuchwałą pewnością siebie. Pokazać, że się nie nad bezduszną masą sprawuje swe bestialskie rządy. Że ten lud sponiewierany obudził się. Że znosi cierpienia do czasu, że nadchodzi długo oczekiwana wiosna ludów"58.

W sierpniu 1942 roku kierownictwo organizacji postanowiło połączyć się z siłami PPR. Decyzja ta była uzasadniona brakiem wyszkolenia wojskowego wśród członków nowej organizacji ${ }^{59}$. Natomiast na przełomie września i października 1942 roku powstało wspólne centrum dowodzenia dla wszystkich żydowskich organizacji konspiracyjnych. Na czele stanęli: Hersz Bauminger, Benek Halbreich, Dolek Liebeskind, Szymon Dränger, Laban, Gola Mire, Elimelech

\footnotetext{
56 Ibidem, s. 69.

57 H. Schüpper-Rufeisen, op. cit., s. 69-71.

58 G. Draenger, op. cit., s. 87.

59 Ibidem, s. 60
} 
Eisenstein. Każda z tych grup kontynuowała własne akcje, ale w strategicznych sprawach decyzje podejmowano wspólnie ${ }^{60}$.

Pierwszymi akcjami, które zorganizowali, były sporadyczne zamachy na Niemców poza gettem - zabicie niemieckiego lotnika, potem żandarma, a także rozkręcanie szyn kolejowych na trasach Kraków-Bochnia i Kraków-Katowice ${ }^{61}$.

W okresie od października do listopada 1942 roku przeprowadzono dwa ataki na firmę Optima - fabrykę niemieckich mundurów, dzięki którym zaopatrzono się w ciepłe ubrania. Adolf Bomberger ${ }^{62}$, który brał udział w tych akcjach, wspominał, że do fabryki dostali się dzięki dorobionym kluczom. Udało im się zdobyć różne materiały, wełnę i buty. W akcji uczestniczyli między innymi Salek Biederman, Mietek Biermer, Henek Wurzel. Ta sama grupa podpaliła barak z autami i oponami przy ul. Miodowej, niedaleko cmentarza żydowskiego ${ }^{63}$.

Bojowcom udało się zdobyć kilka rewolwerów od PPR, dzięki zaangażowaniu i pomocy Goly Mire, a także kilku z nich uzyskało możliwość przebywania poza gettem i ukrywania się w mieszkaniach członków PPR Informację tę podał w relacji Józef Zając, ówczesny komendant Gwardii Ludowej Dzielnicy Zachodniej, który napisał:

W listopadzie Roman skontaktował mnie z Jakubem komendantem grupy żydowskiej. [...] Ulokowaliśmy pewną część tych ludzi na Prądniku ${ }^{64}$, w małych domkach. 18-go grudnia odbyła się konferencja obwodu. [...] Aż do tej konferencji grupa żydowska otrzymała dwie sztuki broni $[\ldots]^{65}$.

Bojowcy zorganizowali kilka kolejnych akcji, między innym w październiku 1942 roku podpalili baraki wojskowe na Grzegórzkach i 2 listopada przeprowadzili, nieudaną, próbę pozbycia się znanego w getcie donosiciela Marcela Grüne$\mathrm{ra}^{66}$. Również w listopadzie Dolek Liebeskind wraz z dwójką innych bojowców zabili niemieckiego policjanta i zabrali jego broń. Akcja miała miejsce u zbiegu ul. Sarego i Starowiślnej ${ }^{67}$.

Ze względu na coraz większy rozgłos dotyczący organizacji i jej akcji członkowie ŻOB, dla bezpieczeństwa, postanowili opuścić getto i schronić się po ,aryjskiej stronie", w mieszkaniach, które przygotowały im łączniczki. Tę funkcję pełniły głównie Hela Rubinek, Ewa Liebeskind (żona Dolka) i Miriam Liebeskind

${ }^{60}$ E. Sztulbach, Powstanie Żydowskiej Organizacji Bojowej ŻOB, AŻIH 301/4803; M. Birner, Archiwum Yad Vashem 0.33/247.

61 E. Sztulbach, Powstanie Żydowskiej Organizacji Bojowej ŻOB, AŻIH 301/4803.

62 Adolf Bomberger, Relacja niezatytułowana, AŻIH 301/1101. Był jednym z kilkunastu Żydów w getcie należących do PPR (od 1942 roku). Brali oni udział w różnych akcjach również poza gettem.

63 Ibidem; Relacja Cesi Frymer i Poli Warszawskiej, s. 5.

${ }^{64}$ Obecnie dzielnica Krakowa.

65 Józef Zając, Relacja niezatytułowana, AŻIH 301/4463.

66 E. Sztulbach, Powstanie Żydowskiej Organizacji Bojowej ŻOB, AŻIH 301/4803.

67 Ibidem; G. Draenger, op. cit., s. 14. 
(siostra Dolka ${ }^{68}$. Ostatnia, symboliczna kolacja w ich dotychczasowym punkcie kontaktowym przy ul. Józefińskiej 13 odbyła się 21 listopada. Gusta Dawidson-Draenger w swoim pamiętniku przytacza słowa, które wypowiedział wówczas Dolek Liebeskind:

$\mathrm{Z}$ naszej drogi nie ma powrotu. Kroczymy szlakiem śmierci, pamiętajcie o tym. Kto pragnie życia niech go nie szuka pośród nas. My jesteśmy u kresu. Tylko że nasz kres nie jest zmierzchem. Nasz kres jest śmiercią, której silny człowiek idzie sam naprzeciw. Czuję, że to ostatnie nasze wspólne powitanie soboty. Trzeba się będzie z dzielnicy usunąć. Zbyt wielki rozgłos jest dookoła nas. W tym tygodniu będziemy likwidować ten nasz miły ośrodek pod trzynastką. Zamknie się jeszcze jedna faza w naszym życiu. Niczego nam jednak nie wolno żałować. Tak musi byćc 69 .

Od tej pory miejscem kontaktowym była jadłodajnia po „aryjskiej stronie” przy ul. św. Filipa oraz punkt na Wielopolu ${ }^{70}$.

\section{Organizacja napadu na Cyganerię}

W mieszkaniu konspiracyjnym PPR 18 grudnia 1942 roku odbyła się tajna narada członków ŻOB i PPR. Opracowano wówczas plan przeprowadzenia większego zamachu w Krakowie ${ }^{71}$. Ponieważ wszystkie dotychczasowe wypady były, jak to nazwały Cesia Frymer i Pola Warszawska: ,akcjami pojedynczymi i znikały w thumnym Krakowie wśród tysiąca innych codziennych spraw. Trzeba było koniecznie zrobić coś, by zwrócić uwagę ludzi"72. Zaplanowano dużą akcję, która miała na celu zdezorientować Niemców. Według relacji Józefa Zająca celem stało się jednoczesne wrzucenie granatów do trzech kawiarni w centrum miasta. Były to Cyganeria, Esplanda i Skala, w których niemieccy oficerowie zwykli się zbierać, a także do klubu oficerskiego Zakopianka. Plan obejmował też podpalenie garaży z pojazdami wojskowymi i sabotaż łodzi SS na Wiśle, rozwieszenie polskich flag na mostach na Wiśle i rozprowadzenie antynazistowskich ulotek w różnych częściach miasta. Dodatkowo planowano zamach na niemieckich żołnierzy w mieście oraz złożenie wieńca w miejscu, gdzie przed wojną stał pomnik Adama Mickiewicza, a który został zniszczony w ciągu pierwszych tygodni okupacji Krakowa. Osobą pracującą nad stworzeniem granatów i bomb był członek Akiby Yeshaya Dreiblatt. Datę operacji ustalono na 22 grudnia 1942 roku, tuż przed świętami Bożego Narodzenia, gdy ulice miasta były wypełnione Niemcami

68 Rejza Klingberg, Napad na Cyganerię, AŻIH 301/1740.

69 G. Draenger, op. cit., s. 101.

70 H. Schüpper-Rufeisen, op. cit., s. 81, 83.

71 Józef Zając, Relacja niezatytułowana, AŻIH 301/4463; Celina Mazela, Mieczysław Zając, Okruchy okupacyjne społeczności żydowskiej w latach 1939-1945, AYV 06/306.

72 Relacja Cesi Frymer i Poli Warszawskiej, s. 6. 
robiącymi zakupy. Oprócz członków ŻOB mieli w niej wziąć udział żydowscy działacze PPR, łącznie 46 osób ${ }^{73}$.

Akcja miała być przeprowadzona $\mathrm{w}$ imieniu polskiego podziemia, aby uchronić się przed niemieckim odwetem w getcie. Przed jej rozpoczęciem Dolek Liebeskind i Szymon Dränger ukryli się po aryjskiej stronie oraz rozkazali wyjechać z Krakowa wszystkim członkom organizacji, którzy nie brali udziału w akcji. Icchak Cukierman wspomina, że przed akcją członkowie krakowskiej organizacji zwrócili się z prośbą, aby ktoś z warszawskiej ŻOB przybył do Krakowa ${ }^{74}$. Dzięki wizycie w Krakowie Arie Wilnera bojowcy warszawscy znali w zarysie plan działania w Krakowie, jednak nie znali daty zamachu, dlatego Cukierman nie śpieszył się z wyjazdem i wraz z Chawką Folman przybył do Krakowa 22 grudnia, w dniu zaplanowanego ataku ${ }^{75}$. Według Cukiermana akcja nie była wystarczająco dobrze zaplanowana, ponieważ nie przewidywała pozostawienia wystarczających sił w getcie. Napisał:

W czasie dyskusji w naszym wewnętrznym sztabie w Warszawie wszyscy byliśmy zgodni w ocenie, że nie wolno przerzucać wszystkich naszych sił walczących w Krakowie na aryjską stronę, nie pozostawiając sił do walki w getcie. Bo przecież przy takiej walce należy uwzględnić co najmniej w 50 procentach niepowodzenie, po którym nie zostanie dość sił do walki w getcie. $Z$ tym stanowiskiem ruszyłem w drogę do Krakowa, zdecydowany zrobić wszystko co można, by ludzie ŻOB-u, którzy przeszli na aryjską stronę, wrócili do getta - po zlikwidowaniu kogo trzeba, zastraszeniu Judenratu i policji żydowskiej, a tym samym zapewnieniu sobie spokoju w getcie $^{76}$.

Jednak po przybyciu do Krakowa okazało się, że jest już za późno na jakiekolwiek zmiany. Cukierman spotkał się z Labanem i udali się do punktu spotkań przy ul. Skawińskiej 24, w opuszczonym budynku, w którym wcześniej znajdował się szpital. Cukierman wspominał:

Znaleźliśmy bojowników siedzących w dwóch pokojach. Laban wyjaśnił im przebieg planowanej akcji, rozdał broń - granaty i pistolety - wybrał główną łączniczkę, ustalił miejsce spotkania i polecił rozejść się, dodając, żeby nikt nie pokazywał nawet czubka nosa przez 48 godzin po akcji ${ }^{77}$.

Akcja powiodła się częściowo i dała powód do dumy uczestnikom. Polskie flagi zawisły na mostach przy ul. Krakowskiej, Mostowej i Starowiślnej. O godzinie $19 \mathrm{w}$ trzech kawiarniach przeprowadzono atak. Największy sukces odniesiono w Cyganerii, gdzie kilku Niemców zostało zabitych, a wielu rannych. Atak na Skalę nie doszedł do skutku, gdyż przedstawienie trwało dłużej, niż się spodziewano i niemieckie oddziały szturmowe nie wyszły z teatru o godzinie 19. Grupa

\footnotetext{
73 Józef Zając, Relacja niezatytutowana, AŻIH 301/4463.

74 I. Cukierman, Nadmiar pamięci, s. 170.

75 Ibidem.

76 Ibidem.

77 Ibidem, s. 172.
} 
wracająca przez Błonia zabiła jednego niemieckiego gestapowca i przejęła jego broń $^{78}$. Rejza Klingberg wspominała: „Sprawcy ulotnili się. Niemcy zaskoczeni, zdziwieni, w strachu, nie wiedzieli, czy ratować swoich rannych i wynosić zabitych, czy szukać sprawców, czy wreszcie ratować siebie samych. Nasi tymczasem wrócili do getta"79.

Po akcji uczestnicy zaczęli się zbierać w umówionym miejscu, jednak wkrótce zostało ono otoczone przez gestapo. Wszyscy, którzy przybyli na ul. Skawińską 24, zostali aresztowani. Rejza Klingberg wspominała, jak po akcji schron został otoczony przez policję. Ponieważ żadna ze złapanych w bunkrze dziewczyn do niczego nie chciała się przyznać, gestapowiec poinformował, że losowo wybierze jedną z nich i zastrzeli. Wybrał autorkę wspomnień. Tak opisała ten moment: ,ja zaś stałam i czekałam na śmierć jak na wyzwolenie. Stałam niemal w upojeniu, wyczekując strzału. Ale nic się nie stało. Wsadzili nas na auto i powieźli na Pomorską na Gestapo"80.

Chawka Folman-Raban opisała akcję aresztowania grupy bojowców w taki sposób:

Cały szpital był otoczony przez dziesiątki, a może setki uzbrojonych Niemców. Wygląda na to, że byli poinformowani o naszej kryjówce, że byliśmy w pułapce. Kazali nam się położyć na podłodze w korytarzu: osobno chłopcy, osobno dziewczęta - twarzami do podłogi. Jeżeli ktoś nawet myślał o ucieczce, wnet zrozumiał, że nie ma to żadnego sensu [...]. Odkryli zapasy broni i ulotek. Wszystko zapakowali w worki. Teraz mieli czas, żeby się zająć nami [...]. Paru Niemców depcze buciorami po leżących chłopcach. Biją pejczami i kolbami karabinów po głowach, aż pojawia się krew. Nie wolno nam podnieść głów. Kopią nas dziko i po jakimś czasie wyrzucają na zewnątrz. Przed bramą szpitala czekają dwa auta. Wpychają nas do nich ${ }^{81}$.

\section{J. Bartko pisat:}

Przeciw Żydom wyruszyły natychmiast dwie grupy gestapowców z Sonderkommando AS-1 i Uberfallkommando der Sipo. Nad ranem przywieziono około dwudziestu osób na Pomorską. Przy aresztowanych znaleziono pistolety, granaty, większą ilość dokumentów. Broń poddano badaniom w Instytucie Kryminalno-Technicznym. Stwierdzono, że z pistoletów tych strzelano do Niemców ${ }^{82}$.

Laban został aresztowany następnego dnia, gdy próbował dostać się na ul. Skawińską 24. Szedł wraz z Cukiermanem, ale okazało się, że Niemcy od czasu odkrycia miejsca spotkania ustawili straż i czekali na powracających bojowców. Cukierman został postrzelony, jednak udało mu się uciec. Laban został przewieziony do więzienia przy ul. Montelupich. Gestapo przeprowadziło rewizję w jego mieszkaniu przy ul. Żuławskiego 3, w którym ukrywali się Dolek Liebes-

\footnotetext{
${ }^{78}$ Rejza Klingberg, Napad na Cyganerię, AŻIH 301/1740.

79 Ibidem.

80 Ibidem.

81 Ch. Folman-Raban, op. cit., s. 83.

82 J. Bratko, op. cit., s. 63.
} 
kind i Idek Tannenbaum. Według relacji Dolek zdążył strzelić do kilku Niemców, zanim sam został zabity ${ }^{83}$.

\section{Bilans}

Różne źródła podają sprzeczne informacje zarówno dotyczące liczby rannych i zabitych Niemców w czasie akcji, jak i konfidentów, którzy zdradzili miejsce spotkania bojowców po akcji. W powojennych publikacjach najczęściej podawane są liczby: 11 zabitych, 13 rannych. Bratko przytacza słowa Heinemeyera, który w powojennym zeznaniu napisał: „Krótko przed Bożym Narodzeniem zostali w Krakowie równocześnie zastrzeleni trzej Niemcy w mundurach i dokonano napadów na niemieckie kawiarnie, gdzie zginęło dwóch Niemców od wybuchów granatów ręcznych" ${ }^{84}$. Liczba ta wydaje się najbardziej prawdopodobna. Również w niemieckim dokumencie, jakim jest protokół konferencji roboczej rządu GG, zanotowano następującą wypowiedź sekretarza stanu Krügera:

Tuż przed Bożym Narodzeniem byliśmy świadkami — zwłaszcza w Krakowie — napadów i prób zamachów, względnie aktów sabotażu, jak je będę odtąd nazywał. [...] Po pierwszych atakach na Niemców nie wiedzieliśmy, z jakiej strony ich dokonano. Chciałbym wyrazić Oberführerowi dr Schöngarthowi wdzięczność za to, że zachował spokój i nie uczynił tego, czego sobie jako szef policji życzyłem i co było w pierwszym rzędzie życzeniem rządu, mianowicie Oberführer dr Schöngarth odstąpił od brutalnej metody aresztowania pierwszych z brzegu stu osób, ustawienia ich pod ścianą i rozstrzelania; zdobył się na cierpliwość i zdołał dotrzeć po nitce do kłębka. W ten sposób udało nam się stwierdzić, z jakich kół wywodzą się sprawcy. W Krakowie na dwa tygodnie przed Bożym Narodzeniem 5 Niemców złożyło swe życie w ofierze: kapitan lotnictwa, urzędnik administracji dystryktu, urzędnik pocztowy, wachmistrz policji i podoficer Wehrmachtu ${ }^{85}$.

Jako że w tekście wyraźnie podano, że chodzi o dwa tygodnie przed Bożym Narodzeniem, a akcja zbrojna w Krakowie odbyła się dwa dni przed świętem, należałoby stwierdzić, że mowa o innych akcjach sabotażowych. W tym okresie w Generalnym Gubernatorstwie Gwardia Ludowa przeprowadziła ich kilka, zwłaszcza w Warszawie i Radomiu ${ }^{86}$. Jednak w samym Krakowie w tym okresie oprócz akcji ŻOB nie było większych ataków na Niemców. Dlatego można wysnuć tezę, że w tekście pojawił się błąd i zamiast dwóch tygodni powinno być dwa dni przed Bożym Narodzeniem, a podana liczba zabitych odnosi się do „napadu na Cyganerię", jak potocznie określa się całokształt tej akcji sabotażowej.

${ }^{83}$ H. Schüpper-Rufeisen, op. cit., s. 85.

84 J. Bratko, op. cit., s. 63.

85 Protokół konferencji roboczej rządu GG, gubernatorów dystryktów oraz przedstawicieli Sipo i SD w sprawach policji i bezpieczeństwa, [w:] Okupacja i ruch oporu w dzienniku Hansa Franka 1939-1945, Warszawa 1970, t. 2, s. 19-20.

86 Ibidem, s. 19, przyp. 132. 
Natomiast jako konfidentów Chawka Folman-Raban ${ }^{87}$ wskazuje Julka Appla i Nathana Weismana, którzy współpracowali z ludźmi z ŻOB w Krakowie. Julian Appel należał do najaktywniejszej żydowskiej grupy konfidentów, która była nazywana żydowskim gestapo ${ }^{88}$. W zeznaniach złożonych przed Komisją Historyczną w Krakowie Marian Faber ${ }^{89}$, powołując się na spotkanego w celi w więzieniu przy ul. Montelupich więźnia Argasińskiego, podaje, że osobą, która doniosła gestapo o miejscu spotkania po akcji, była Marta Puretz ${ }^{90}$. Józef Brat$\mathrm{ko}^{91}$ podaje informację na podstawie zeznań Heinemeyera, że to Rudolf Schmeidler był konfidentem, który od dłuższego czasu pracował nad rozbiciem ŻOB, i zdradził miejsce kryjówki ${ }^{92}$.

\section{Dalsze losy bojowców}

Chawka Folman i Rejza Klingberg zostały wysłane do KL Auschwitz ${ }^{93}$. Szymon Dränger został aresztowany 10 stycznia 1943 roku. Jego żona Gusta poszukiwała go na wszystkich posterunkach policji, w końcu sama oddała się w jej ręce. Wraz z nią aresztowano Romka Lustgartena, który pomagał Guście w poszukiwaniu męża. Przetrzymywana była w więzieniu przy ul. Helclów, w celi nr $15^{94}$.

Pozostali bojowcy, którym do tego czasu udało się uniknąć aresztowania, podejmowali próby uwolnienia swoich przywódców. Hela Schüpper wyjechała do Warszawy, aby zdobyć pieniądze niezbędne do podjęcia starań o uwolnienie bojowców $z$ więzienia ${ }^{95}$.

Większość członków i przywódców Akiby i Droru zostało zamordowanych lub aresztowanych. Doprowadziło to do rozpadu organizacji.

Po aresztowaniach bojowców do getta krakowskiego przybyła mała grupa konspiracyjna z Rzeszowa, związana z PPR. Składała się z Żydów, którzy uciekli z getta w Rzeszowie ${ }^{96}$ i postanowili ukryć się w getcie krakowskim. Byli to młodzi ludzie w wieku 18-20 lat, wywodzili się z przedwojennego ruchu Ha-Szomer.

87 Ch. Folman-Raban, op. cit., s. 84.

88 Grupa konfidentów miała swoją melinę przy ul. Sławkowskiej 6. Inni konfidenci: Maurycy Diamand, Stefania Brandstaetter (Anita), Nina Daniłowicz, Zofia Przyboś (Czikita), Krystyna D. (piękna Krysia).

89 Marian Faber, W sprawie Marty Puretz, AŻIH 301/1940.

90 Warto zwrócić uwagę na publikację Aleksandry Kasznik-Christian, w której przeprowadzona została analiza losów Marty Puretz i kierowanych w stosunku do niej oskarżeń. Zob. A. Kasznik-Christian, Sprawa Marty Puretz, domniemanej agentki Gestapo z krakowskiego getta, „Zagłada Żydów. Studia i Materiały” 2020, nr 16, s. 629-662.

91 J. Bratko, op. cit., s. 63.

92 Ibidem, s. 74-75.

93 C. Lubetkin, op. cit., s. 87.

94 H. Schüpper-Rufeisen, op. cit., s. 86.

95 Ibidem.

96 W Rzeszowie byli poszukiwani przez gestapo. 
Należeli do nich między innymi Lejbek, Józek Men, Moniek Traum, Sabka Licht, Wuśka Jelles; 31 grudnia 1942 roku zorganizowali zamach na szefa wydziału cywilnego OD Blodka, jednak akcja okazała się nieskuteczna ${ }^{97}$.

W styczniu 1943 roku odbyła się narada, w której uczestniczyli Herz Bauminger, Benek Halbreich oraz przedstawiciele Gwardii Ludowej. Postanowili dalej prowadzić działalność przeciwko Niemcom. Za pierwszy cel wybrano atak na Arbeitsamt - niemieckie biuro pracy przy ul. Lubelskiej 27. W podpaleniu urzędu brali udział członkowie organizacji Iskra. Dzięki tej akcji zostało zniszczonych większość dokumentów osobistych i akt ${ }^{98}$.

OD udało się 16 lutego 1943 roku sporządzić dokładną listę członków ruchu konspiracyjnego. Było to możliwe dzięki donosom. Roman Bromberger, który był pracownikiem OD, dowiedziawszy się o tym, ostrzegł kolegów i uciekł z getta. Inni poszli w jego ślady, jednak nie dla wszystkich ucieczka zakończyła się pomyślnie ${ }^{99}$. Za sprawą donosu 19 lutego zastrzelono Benjamina Halbreicha. Również w lutym został aresztowany Hersz Bauminger, który wkrótce zmarł w więzieniu. Kilka dni później do aresztu trafiła Gola Mire, która w celi spotkała Gustę ${ }^{100}$. Cesia Frymer i Pola Warszawska wspominały:

\begin{abstract}
Getto wymarło, ludzie zrozumieli, że nie ma tu już co szukać i jedyne wyjście, to przerzucić się na drugą stronę. [...] Następuje wsypa po wsypie. Wpadają prawie wszyscy ludzie, wpadają magazyny żywnościowe i odzieżowe, drukarki i magazyny z bronią i granatami na Bonarce, Powiślu i alei Słowackiego ${ }^{101}$.
\end{abstract}

W getcie pozostała garstka działaczy. Udało im się skomunikować z przebywającymi poza gettem. Łącznikami w getcie zostali Tulek Rab i Tysiu z Bochni. W getcie krążyły pogłoski o likwidacji, w związku z tym zakonspirowana młodzież postanowiła zbudować bunkier w części getta B, aby przetrwać likwidację. We wspomnieniach czytamy: „Plan jest gotowy — bunkier ma zostać zbudowany $w$ getcie $B$, nad mieszkaniem jednego z ludzi. Praca jest ciężka i niebezpieczna - wszystko trzeba robić po nocy - z jednej strony nosić cegły i wapno z getta A, a z drugiej budować cichaczem, by się nie zdradzić"102. Bunkier udało się ukończyć przed akcją likwidacyjną. W czasie likwidacji ukryło się $\mathrm{W}$ nim około dwudziestu osób. Jednak miejsce kryjówki zostało zdradzone, a ukrywający się zastrzeleni.

Kilku działaczy organizacji bojowych zdołało przetrwać likwidację getta i podjąć próby porozumienia się między sobą, przebywając w obozach pracy.

Dwie łączniczki ŻOB Helę Rubinek oraz Szchorę Dränger, siostrę Szymona, zastrzelono 19 marca; 20 marca przeprowadzono egzekucję Mońka Eisensteina,

97 Relacja Cesi Frymer i Poli Warszawskiej, s. 6-8.

98 Józef Zając, Relacja niezatytułowana, AŻIH 301/4463.

99 Relacja Cesi Frymer i Poli Warszawskiej, s. 8.

100 Ibidem, s. 9.

101 Ibidem, s. 8-9.

102 Ibidem, s. 9. 
który był jednym z przywódców ŻOB; 13 kwietnia do obozu w Auschwitz wywiezieni zostali między innymi Józek Wolf i Poldek Wassermann ${ }^{103}$.

Zarówno Szymon Dränger, jak i jego żona postanowili spróbować ucieczki z więzienia. Szymon 29 kwietnia był przewożony z więzienia wraz z Labanem. W czasie transportu napadli na pilnujących ich strażników. Szymonowi udało się uciec. Lejbowicz został zastrzelony w obozie Płaszów ${ }^{104}$. Tego samego dnia miała odbyć się egzekucja kobiet związanych z ŻOB. Próbę ucieczki podjęła również żona Szymona Gusta. Gdy przeprowadzano kobiety do więzienia przy ul. Montelupich, te postanowiły rozbiec się we wszystkich kierunkach. Ich plan zakładał, że żadna nie udziela pomocy innej i nie ogląda się za siebie. Miały biec przed siebie, z nadzieją, że choć jednej uda się przeżyć. Tym sposobem Gusta i Genia Melcer się uratowały. Gola Mire została rozstrzelana. Szymon i Gusta zaczęli na nowo organizować żydowskie grupy partyzanckie w Bochni, zostali aresztowani i rozstrzelani w listopadzie 1943 roku $^{105}$.

W sierpniu 1943 roku Bojowa Organizacja Żydowskiej Młodzieży Chalucowej wydała odezwę następującej treści:

Do resztek na ziemi polskiej ginącego ludu żydowskiego. Do Was, którzyście najbliżsi nam i w imię których wyruszyliśmy w bój, zwracamy się znad nieznanych mogił najlepszych i najdroższych nam towarzyszy, co padli w nierównej walce. Zawsze pragnęliśmy wolnego życia, lecz jeśli trzeba zginąć, to chcemy paść w postawie bojowej, by ponieść śmierć dumną i godną. Nie wyszliśmy po zwycięstwo orężne - nie nam było dane je odnieść, ale wyszliśmy bronić ducha, a ducha wszak wróg w nas nie zabił. Bo śmierć nie jest klęską ani hańbą, a siła przemocy, co pokonuje garstkę powstańców — nie jest zwycięstwem. Dopięliśmy swego celu, chwyciliśmy za broń, bo nie mogliśmy pogodzić się z myślą, że w bestialski sposób giną tysiące żydowskich mężczyzn, kobiet, starców i dzieci; bo nie chcieliśmy dać się pognać, niczym barany na rzeź; bo nie chcieliśmy, by kiedyś historia powiedziała, że żydostwo polskie zginęło marnie, bez słowa sprzeciwu ${ }^{106}$.

\section{Bibliografia}

\section{Archiwa}

Archiwum Żydowskiego Instytutu Historycznego w Warszawie (AŻIH)

Relacje. Zeznania ocalałych Żydów, sygn. 301.

Archiwum Yad Vashem (AYV).

Borowicz Collection, sygn. O.62.

Poland Collection, sygn. O.6.

103 A. Bieberstein, op. cit., s. 240-246.

104 I. Cukierman, Nadmiar pamięci, s. 176; Roman Kaliński, Ucieczka z Montelupich, AŻIH 301/1754.

105 J. Wulf, Symek i Gusta, „Dos Naje Lebn” 21.11.1945, AŻIH 301/1681; Wanda Lewicka, Relacja niezatytułowana, AŻIH 301/2423.

106 H. Schüpper-Rufeisen, op. cit., s. 6. 


\section{Publikacje}

Agatstein-Dormontowa D., Żydzi w Krakowie w okresie okupacji niemieckiej, [w:] Kraków w latach okupacji 1939-1945. Studia i materiaty, („Rocznik Krakowski” 31), Kraków 1949-1957.

Bauminger A., The Fighters of the Cracow Ghetto, Jerusalem 1986.

Bieberstein A., Zagłada Żydów w Krakowie, Kraków 1985 i 2001.

Bratko J., Gestapowcy, Kraków 1985.

Cukierman I., The Jewish Fighting Organization - Z.O.B. — its establishment and activities, Jerusalem 1976.

Cukierman I., Nadmiar pamięci. Siedem owych lat. Wspomnienia 1939-1946, Warszawa 2000.

Długosz E., Draenger G., [w:] Wojna to męska rzecz? Losy kobiet w okupowanym Krakowie w dwunastu odstonach, red. A. Czocher, D. Kałwa, B. Klich-Kluszewska, B. Łabno, Kraków 2011.

Draenger G., Pamiętnik Justyny, Kraków 1946.

Folman-Raban C., Nie rozstawatam się z nimi..., Warszawa 2000.

Grądzka-Rejak M., Kobieta żydowska w okupowanym Krakowie (1939-1945), Kraków 2016.

Grądzka-Rejak M., Ruch oporu w gettach i obozach, (seria „Polska walcząca”), Warszawa 2017.

Jarkowska Natkaniec A., Wymuszona wspótpraca czy zdrada? Wokół kolaboracji Żydów w okupowanym Krakowie, Kraków 2018.

Kołodziejska K., Gusta Dawidson-Draenger — kronika żydowskiego ruchu oporu w Krakowie, [w:] Przewodniczka po Krakowie emancypantek, t. 4, red. E. Furgał, Kraków 2012.

Libionka D., Weinbaum L., Bohaterowie, hochsztaplerzy, opisywacze. Wokól Żydowskiego Zwiazku Wojskowego, Warszawa 2011.

Löw A., Roth M., Krakowscy Żydzi pod okupacja niemiecka 1939-1945, Kraków 2014.

Lubetkin C., Zagłada i powstanie, Warszawa 1999.

Mariańska M., Mariański M., Wśród przyjaciól i wrogów. Poza gettem w okupowanym Krakowie, Kraków 1988.

Michman D., Holocaust Historiography. A Jewish Perspective, London-Portland, Or 2003.

Natkaniec M., Żydowska konspiracja zbrojna w Krakowie i rejonie krakowskim w okresie okupacji hitlerowskiej, „Krzysztofory” 1988, nr 15.

Nirensztein A., Ruch oporu Żydów w Krakowie pod okupacją hitlerowska, „Biuletyn Żydowskiego Instytutu Historycznego" 1952, nr 3.

Okupacja i ruch oporu $w$ dzienniku Hansa Franka 1939-1945, t. 1-2, oprac. S. Płoski, L. Dobroszycki, J. Garas, M. Getter, L. Herzog, A. Janowski, M. Malinowski, Warszawa 1970.

Rotem S., Wspomnienia bojowca ŻOB, Warszawa 1993.

Ruch podziemny $w$ gettach $i$ obozach. Materiaty i dokumenty, oprac. B. Ajzensztajn, Warszawa-Łódź-Kraków 1946.

Rufeisen-Schüpper H., Pożegnanie Miłej 18, Kraków 1996.

Skibińska A., Źródła do badań nad zagładą Żydów na okupowanych ziemiach polskich. Przewodnik archiwalno-bibliograficzny, Warszawa 2007.

Swałtek-Niewińska D., Powiat bocheński, [w:] Dalej jest noc. Losy Żydów w wybranych powiatach okupowanej Polski, red. B. Engelking, J. Grabowski, Warszawa 2018.

Szatyn B., Na aryjskich papierach, Kraków 1983.

Ten jest z ojczyzny mojej. Polacy z pomoca Żydom 1939-1945, red. W. Bartoszewski, Z. Lewinówna, Kraków 1969.

Wroński T., Zachwieja E., Szkolnictwo podstawowe miasta Krakowa w okresie okupacji hitlerowskiej 1939-1945. (Wybór dokumentów), Warszawa 1977. 
Zajączkowska-Drożdż A., Od dyskryminacji do eksterminacji. Polityka Trzeciej Rzeszy wobec Żydów w Krakowie 1939-1943, Kraków 2020.

Zimmerer K., Kronika zamordowanego świata. Żydzi w Krakowie w czasie okupacji niemieckiej, Kraków 2017.

Zimmerer K., Zamordowany świat. Losy Żydów w Krakowie 1939-1945, Kraków 2004.

Zimmermann Zwi H., Przeżyłem, pamiętam, świadczę, Kraków 1997.

Życie i zagłada Żydów polskich 1939-1945. Relacje świadków, oprac. M. Grynberg, M. Kotowska, Warszawa 2003. 